\title{
PENGARUH PROFITABILITAS, LEVERAGE, STRUKTUR KEPEMILIKAN DAN STATUS PERUSAHAAN TERHADAP \\ PENGUNGKAPAN LAPORAN KEUANGAN PADA PERUSAHAN MANUFAKTUR YANG TERDAFTAR DI BURSA EFEK INDONESIA
}

\author{
Desi Natalia Br Sinurat \\ Eddy Rismanda Sembiring
}

\begin{abstract}
Abstrak
Penelitian ini bertujuan untuk menganalisis pengaruh profitabilitas, leverage, struktur kepemilikan dan status perusahaan terhadap pengungkapan laporan keuangan. Teknik pengambilan sampel yang digunakan adalah random sampling dengan menggunakan rumus slovin, dengan jumlah sampel 58 perusahaan. Data diperoleh dari Bursa Efek Indonesia dari tahun 2012-2013. Teknik analisis data yang dipergunakan adalah analisis regresi linear berganda. Hasil koefisien determinasi sebesar 0.117 hal ini berarti bahwa besarnya kemampuan variable independen untuk menjelaskan variable devenden adalah $11.7 \%$ dan sisanya sebesar $88.3 \%$ dipengaruhi oleh faktor-faktor lain yang tidak dimasukkan dalam model regresi. Berdasarkan hasil analisis regresi uji $\mathrm{F}$ menunjukkan bahwa profitabilitas (ROA), leverage (DER), kepemilikan institusional dan status perusahaan secara simultan berpengaruh positif dan signifikan terhadap pengungkapan laporan keuangan pada perusahaan manufaktur yang terdaftar di Bursa Efek Indonesia. Berdasarkan hasil analisis regresi uji t menunjukkan bahwa profitabilitas (ROA) berpengaruh negatif dan signifikan, leverage (DER) berpengaruh positif dan tidak signifikan, kepemilikan institusional memiliki pengaruh negatif dan signifikan, dan status perusahaan memiliki pengaruh positif dan tidak signifikan terhadap pengungkapan laporan keuangan pada perusahaan manufaktur yang terdaftar di Bursa Efek Indonesia. Berdasarkan hasil penelitian dapat disimpulkan bahwa profitabilitas, leverage, struktur kepemilikan dan status perusahaan berpengaruh terhadap lengkap atau tidaknya pengungkapan laporan keuangan. Saran yang diberikan kepada peneliti selanjutnya hendaknya menggunakan variabel-variabel lain yang mempengaruhi pengungkapan laporan keuagan.
\end{abstract}

Kata Kunci : Profitabilitas, Leverage, Struktur Kepemilikan, Status Perusahaan, Pengungkapan Laporan Keuangan

\section{PENDAHULUAN}

Dunia bisnis merupakan suatu topik yang hangat dan menarik untuk diperbincangkan. Dunia bisnis dapat dikatakan sebagai salah satu tolak ukur dari kemajuan perekonomian suatu negara tetapi lingkungan ekonomi yang berubah-ubah dan ketatnya persaingan sangat berpengaruh pada dunia usaha. Untuk dapat bersaing, perusahaan dihadapkan pada kondisi 
untuk dapat lebih transparan dalam mengungkapkan informasi sehingga dapat membantu para pengambil keputusan dalam mengantisipasi kondisi ekonomi yang semakin berubah.

Bagi pihak-pihak diluar manajemen suatu perusahaan, laporan keuangan merupakan jendela informasi yang memungkinkan mereka mengetahui kondisi perusahaan tersebut. Laporan keuangan dipublikasikan setelah di audit. Audit laporan keuangan bertujuan bukan untuk menciptakan informasi baru, melainkan untuk menambahkan keandalan laporan keuangan yang telah disusun oleh manajemen. Manajemen bertanggungjawab untuk menyusun laporan keuangan sedangkan auditor bertanggungjawab untuk mematuhi standar auditing yang berlaku umum dalam mengumpulkan dan mengevaluasi bukti, serta dalam menerbitkan laporan yang memuat kesimpulan auditor yang dinyatakan dalam bentuk pendapat atau opini atas laporan keuangan. Sehingga manajemen dan auditor bertanggungjawab atas laporan keuangan. Sejauh mana informasi yang dapat diperoleh dari laporan keuangan akan sangat tergantung pada seberapa besar tingkat pengungkapan (disclosure) laporan keuangan yang bersangkutan.

Pengungkapan (disclosure) yang disampaikan perusahaan dapat dibagi menjadi pengungkapan wajib dan sukarela. Pengungkapan wajib merupakan pengungkapan minimum yang diwajibkan oleh peraturan bapepam. Di Indonesia peraturan mengenai pengungkapan informasi dalam laporan tahunan diatur dalam Surat Keputusan Ketua Badan Pengawas Pasar Modal No:Kep-347/BL/2012 diatur dalam peraturan No.VIII.G.7 tanggal 25 Juni 2012 tentang penyajian dan pengungkapan laporan keuangan emiten atau perusahaan publik, mensyaratkan item-item yang harus diungkapkan dalam laporan keuangan perusahaan-perusahaan publik di Indonesia.

Dalam penelitian yang dilakukan oleh Arumi Purwandari (2012), profitabilitas , dan kepemilikan manajerial berpengaruh signifikan terhadap pengungkapan laporan keuangan sedangkan leverage dan status perusahaan tidak berpengerauh signifikan terhadap pengungkapan laporan keuangan. Sedangkan penelitian yang dilakukan Wiwik Pujiati (2011) menghasilkan NPM dan DAR berpengaruh signifikan terhadap pengungkapan laporan keuangan. CR, Ukuran Perusahaan, Umur Perusahaan dan Porsi Kepemilikan Saham tidak berpengerauh signifikan terhadap pengungkapan laporan keuangan. 
Berdasarkan fenomena dari hasil penelitian terdahulu yang berbedabeda maka penulis ingin meneliti kembali tentang pengungkapan laporan keuangan dengan mengambil judul: "Pengaruh Profitabilitas, Leverage, Struktur Kepemilikan dan Status Perusahaan terhadap Pengungkapan Laporan Keuangan Pada Perusahaan Manufaktur yang terdaftar di Bursa Efek Indonesia".

\section{TINJAUAN PUSTAKA DAN PENGEMBANGAN HIPOTESIS}

\section{Pengungkapan Laporan Keuangan}

Pengungkapan laporan keuangan menyediakan informasi yang berguna bagi investor dan kreditor sekarang dan yang potensial serta pemakai lainnya dalam mengambil keputusan investasi, kredit dan keputusan serupa secara rasional. Pengungkapan laporan keuangan tidak hanya ditujukan bagi pemegang saham, tetapi juga ditujukan kepada kepentingan pemegang andil (stakholders). Laporan keuangan ditujukan untuk memberikan informasi umum kepada semua pemakai selain pemegang saham yang mengemban tanggung jawab pengendalian dan manajemen organisasi.

Menurut Harahap (2007:268) ada tiga konsep pengungkapan, yaitu :

a. Pengungkapan memadai (adequate disclosure)

Konsep yang sering digunakan adalah pengungkapan yang cukup, yaitu pengungkapan yang minimum yang disyaratkan oleh peraturan yang berlaku, dimana angka-angka yang disajikan dapat diinterpretasikan dengan benar oleh investor.

b. Pengungkapan wajar (Fair Disclosure)

Pengungkapan yang wajar secara tidak langsung menyiratkan suatu etika, yaitu memberikan perlakuan yang sama kepada semua pemakai laporan keuangan.

c. Pengukapan penuh (Full disclosure)

Pengungkapan penuh menyangkut penyajian informasi yang relevan. Bagi sebagian orang pengungkapan penuh berarti penyajian informasi secara berlimpah sehingga tidak tepat. Namun, terlalu banyak informasi akan membahayakan, karena penyajian rinci dan yang tidak penting justru akan mengamburkan informasi yang signifikan membuat laporan keuangan sulit ditafsir. 
Menurut keputusan Bapepam No. Kep-06/PM/2000 terdapat dua jenis pengungkapan, antara lain :

1. Pengungkapan wajib (mandatory disclosure)

Pengungkapan wajib merupakan pengungkapan minimum yang harus diungkapkan atau diisyaratkan oleh peraturan bapepam.

2. Pengungkapan sukarela (Voluntary disclosure)

Pengungkapan sukarela merupakan pengungkapan yang tidak diwajibkan peraturan yang berlaku, dimana perusahaan bebas memilih jenis informasi yang akan diungkapkan yang sekiranya mendukung dalam pengambilan keputusan atau pengungkapan yang melebihi pengungkapan wajib. Pengungkapan ini berupa item-item yang diungkapkan secara sukarela oleh perusahaan.

Dalam menghitung indeks pengungkapan (disclosure), penulis menggunakan indeks Wallace yang mengungkapkan perbandingan antara jumlah item yang diungkapkan dengan jumlah item yang seharusnya diungkapkan

Indeks Wallace adalah instrumen yang digunakan untuk mengukur berapa banyak informasi laporan keuangan yang material yang diungkapkan oleh perusahaan. Semakin banyak item yang diungkapkan oleh perusahaan, semakin banyak juga angka indeks yang diperoleh perusahaan, dengan rumus sebagai berikut :

\section{Indeks wallace $=\frac{\mathbf{n}}{\mathbf{N}}$}

$\mathrm{n}=$ jumlah butir pengungkapan yang terpenuhi

$\mathrm{N}=$ jumlah butir pengungkapan yang mungkin terpenuhi keseluruhan

Perusahaan dengan angka indeks yang lebih tinggi menunjukkan bahwa perusahaan tersebut telah melakukan pengungkapan secara lebih komprehensif dibanding perusahaan lain.

\section{Rasio Profitabilitas}

Profitabilitas merupakan kemampuan perusahaan untuk memperoleh laba melalui semua kemampuan dan sumber daya yang ada seperti kegiatan penjualan, asset dan modal saham. Menurut Kasmir (2008) rasio profitabilitas merupakan rasio untuk menilai kemampuan perusahaan dalam mencari keuntungan. Profitabilitas merupakan kemampuan dan keefisienan pihak manajemen dalam menggunakan assetnya untuk menghasilkan laba (Dewi Agustina, 2006). 
Profitabilitas bertujuan untk mengukur efisiensi aktivitas perusahaan dan kemampuan perusahaan untuk memperoleh keuntungan dan untuk memperoleh keuntungan tersebut pengelola perusahaan harus mampu bekerja secara efisien serta kinerja perusahaan harus senantiasa ditingkatkan. Dalam penelitian ini untuk mengukur profitabilitas digunakan rasio Return on Asset. Rasio Return on Asset mengukur kemampuan perusahaan menghasilkan laba bersih berdasarkan tingkat asset. Rasio yang tinggi menunjukkan efektivitas manajemen dalam menggunakan asset untuk memperoleh pendapatan. Rumus untuk menghitung ROA adalah :

$$
\mathrm{ROA}=\frac{E A T}{\text { Total Asset }}
$$

\section{Rasio Leverage}

Perusahaan memperoleh dana dari dua sumber yaitu kreditor dan pemegang saham. Leverage menunjukkan seberapa besar perusahaan didanai oleh kreditor dan pemegang saham. Menurut Kasmir (2008) "rasio solvabilitas atau rasio leverage merupakan rasio yang digunakan untuk mengukur sejauh mana aktivitas perusahaan dibiayai dengan hutang". Sehingga rasio solvabilitas atau rasio leverage dapat diartikan sebagai rasio yang digunakan untuk menilai sejauh mana perusahaan menggunakan uang yang dipinjamnya.

Menurut Stice (2005) "para investor biasanya lebih menginginkan leverage yang tinggi untuk meningkatkan ukuran perusahaan mereka tanpa harus meningkatkan investasi mereka, tetapi para kreditor lebih memilih leverage yang rendah untuk meningkatkan keamanan pinjaman mereka".

Leverage atau solvabilitas menunjukkan seberapa besar ekuitas yang tersedia untuk memberikan jaminan terhadap hutang. Hutang disini meliputi hutang lancar dan jangka panjang. Dalam penelitian ini untuk mengukur Leverage digunakan Debt to Equity ratio.Keseimbangan proporsi antara aktiva yang didanai oleh kreditor dan yang didanai oleh pemilik perusahaan dapat diukur dengan Debt to Equity ratio (DER). DER juga dapat memberikan gambaran tentang struktur modal yang dimiliki perusahaan. Rumus untuk menghitung debt to equity adalah :

$$
\text { Debt to equity ratio }=\frac{\text { Total Hutang }}{\text { Total Ekuitas }}
$$

\section{Struktur Kepemilikan Perusahaan}

Tujuan perusahaan sangat berpengaruh terhadap struktur kepemilikan. Pemilik akan berusaha membuat berbagai strategi untuk mencapai tujuan 
perusahaan, setelah strategi ditentukan maka langkah selanjutnya akan mengimplementasikan strategi dan mengalokasikan sumber daya yang dimiliki perusahaan untuk mencapai tujuan perusahaan. Semua tahap tersebut tidak terlepas dari peran pemilik atau dapat dikatakan bahwa peran pemilik sangat penting dalam menentukan keberlangsungan perusahaan.

Dalam penelitian ini untuk mengukur struktur kepemilikan digunakan kepemilikan institusional. Kepemilikan institusional adalah kepemilikan saham oleh badan institusi, seperti institusi keuangan, bank, dan perusahaan lain. Kepemilikan institusional dapat dihitung dengan cara membandingkan antara jumlah saham yang dimiliki oleh institusional dengan total saham perusahaan yang beredar. Rumus untuk menghitung Kepemilikan institusional adalah:

$$
\text { Kepemilikan institusional }=\frac{\text { Jumla } h \text { saham yang dimiliki Institusi }}{\text { Jumla } h \text { saham yang beredar }}
$$

\section{Status Perusahaan}

Latar belakang masuknya variabel status perusahaan didorong oleh suatu alasan sederhana yaitu bahwa perusahaan dengan status yang berbeda akan memiliki stakeholderyang berbeda, sehingga tingkat pengungkapan yang harus dilakukan berbeda (Dewi Agustina, 2006). Perusahaan yang berbasis asing (PMA) mungkin melakukan pengungkapan yang berbeda dibanding perusahaan yang berbasis dalam negeri (PMDN). Hal ini dikarenakan :

1. Perusahaan berbasis asing mendapatkan pelatihan (misalnya dalam bidang akuntansi) dari perusahaan induknya di luar negeri

2. Perusahaan berbasis asing mungkin mempunyai sistem akuntansi yang berbeda untuk memenuhi kebutuhan pengendalian intern dan kebutuhan informasi perusahaan induknya

3. Perusahaan asing memiliki permintaan informasi yang lebih besar dari pelanggan, pemasok, analis dan masyarakat pada umumnya.

Perusahaan-perusahaan dengan status yang berbeda akan memiliki Stakeholder yang berbeda, sehingga tingkat pengungkapan wajib laporan keuangan yang diungkapkan juga berbeda. Penelitian yang dilakukan oleh Fitrian (2001) menyimpulkan bahwa status perusahaan berpengaruh signifikan terhadap kelengkapan pengungkapan wajib laporan keuangan.

Penelitian yang dilakukan oleh Dewi Agustina (2006) memperoleh hasil bahwa status perusahaan tidak berpengaruh signifikan terhadap pengungkapan laporan keuangan, namun secara teori dengan status 
perusahaan yang baik akan semakin luas pengungkapan laporan keuangan perusahaan

\section{Penelitian Terdahulu}

Tabel 1. Ringkasan Penelitian Terdahulu

\begin{tabular}{|c|c|c|c|c|}
\hline $\begin{array}{l}\mathrm{N} \\
\mathrm{O}\end{array}$ & $\begin{array}{l}\text { Nama } \\
\text { peneliti }\end{array}$ & $\begin{array}{c}\text { Sampel dan } \\
\text { Periode Penelitian }\end{array}$ & $\begin{array}{c}\text { Variabel dan Metode } \\
\text { Analisis Data }\end{array}$ & Hasil Penelitian \\
\hline 1 & $\begin{array}{l}\text { Dewi } \\
\text { Agustina } \\
(2006)\end{array}$ & $\begin{array}{l}\text { Sampel sebanyak } \\
69 \text { perusahaan } \\
\text { manufaktur di } \\
\text { BEJ } \\
\text { Periode penelitian } \\
2004-2005\end{array}$ & $\begin{array}{l}\text { Variabel bebas : } \\
\text { profitabilitas, } \\
\text { leverage, kepemilikan } \\
\text { publik dan status } \\
\text { Variabel terikat : } \\
\text { pengungkapan } \\
\text { laporan keuangan } \\
\text { Metode analisis data } \\
\text { menggunakan regresi } \\
\text { linear berganda }\end{array}$ & $\begin{array}{l}\text { Profitabilitas (ROA), } \\
\text { leverage dan status } \\
\text { perusahaan tidak } \\
\text { berpengaruh terhadap } \\
\text { pengungkapan } \\
\text { laporan keuangan } \\
\text { Kepemilikan publik } \\
\text { berpengaruh terhadap } \\
\text { pengungkapan } \\
\text { laporan keuangan }\end{array}$ \\
\hline 2 & $\begin{array}{l}\text { Kumala } \\
\text { Dewi } \\
(2008)\end{array}$ & $\begin{array}{l}\text { Sampel sebanyak } \\
37 \text { perusahaan } \\
\text { manufaktur BEJ } \\
\text { Periode penelitian } \\
: 2005-2007\end{array}$ & $\begin{array}{l}\text { Variabel bebas : } \\
\text { DER,CR,ROA,OPM, } \\
\text { Presentase } \\
\text { kepemilikan } \\
\text { manajerial, porsi } \\
\text { saham dan ownersip } \\
\text { dan gross profit } \\
\text { margin } \\
\text { Variabel terikat : } \\
\text { pengungkapan } \\
\text { laporan keuangan } \\
\text { Metode analisis data } \\
\text { menggunakan } \\
\text { Regresi linear } \\
\text { berganda }\end{array}$ & $\begin{array}{l}\text { CR mempengaruhi } \\
\text { luas pengungkapan } \\
\text { laporan keuangan } \\
\text { tahunan secara positif } \\
\text { ROA.OPM,DER, } \\
\text { Porsi saham publik, } \\
\text { presentase } \\
\text { kepemilikan } \\
\text { manajerial, gros } \\
\text { profit margin tidak } \\
\text { berpengaruh terhadap } \\
\text { luas pengungkapan } \\
\text { laporan keuangan } \\
\text { perusahaan }\end{array}$ \\
\hline 3 & $\begin{array}{l}\text { Wiwik } \\
\text { pujiati } \\
(2011)\end{array}$ & $\begin{array}{l}\text { Sampel sebanyak } \\
33 \text { perusahaan } \\
\text { real estate } \\
\text { Periode penelitian } \\
(2009-2011)\end{array}$ & $\begin{array}{l}\text { Variabel bebas : CR, } \\
\text { NPM, DAR,Ukuran } \\
\text { Perusahaan, umur } \\
\text { perusahaan dan } \\
\text { kepemilikan saham } \\
\text { publik } \\
\text { Variabel terikat : } \\
\text { pengungkapan } \\
\text { laporan keuangan } \\
\text { Metode analisis data } \\
\text { menggunakan regresi } \\
\text { linear berganda }\end{array}$ & $\begin{array}{l}\text { Variabel NPM, } \\
\text { DAR,Kepemilkan } \\
\text { Saham Publik } \\
\text { berpengaruh terhadap } \\
\text { luasnya } \\
\text { pengungkapan } \\
\text { laporan keuangan } \\
\text { Variabel CR,Ukuran } \\
\text { perusahaan dan umur } \\
\text { perusahaan tidak } \\
\text { berpengaruh terhadap } \\
\text { luas pengungkapan } \\
\text { sukarela dalam } \\
\text { laporan }\end{array}$ \\
\hline
\end{tabular}




\begin{tabular}{|c|c|c|c|c|}
\hline 4 & $\begin{array}{l}\text { Arumi } \\
\text { Purwandar } \\
\text { i (2012) }\end{array}$ & $\begin{array}{l}\text { Sampel sebanyak } \\
96 \text { perusahaan } \\
\text { manufaktur } \\
\text { Periode penelitian } \\
2009-2010\end{array}$ & $\begin{array}{l}\text { Variabel bebas : } \\
\text { profitabilitas, } \\
\text { leverage, kepemilikan } \\
\text { institusional, } \\
\text { kepemilikan publik, } \\
\text { kepemilikan } \\
\text { manajerial, status } \\
\text { perusahaan } \\
\text { Variabel terikat : } \\
\text { pengungkapan } \\
\text { laporan keuangan } \\
\text { Metode analisis data } \\
\text { menggunakan regresi } \\
\text { linear berganda }\end{array}$ & $\begin{array}{l}\text { kepemilikan } \\
\text { institusional, } \\
\text { kepemilikan publik, } \\
\text { kepemilikan } \\
\text { manajerial, } \\
\text { berpengaruh } \\
\text { signifikan terhadap } \\
\text { pengungkapan } \\
\text { laporan keuangan } \\
\text { sedangkan } \\
\text { profitabilitas, } \\
\text { leverage, dan status } \\
\text { perusahaan tidak } \\
\text { signifikan terhadap } \\
\text { pengungkapan } \\
\text { laporan keuanagan }\end{array}$ \\
\hline
\end{tabular}

\section{Perumusan Hipotesis}

Hipotesis adalah suatu penjelasan sementara tentang perilaku, fenomena, atau keadaan tertentu yang telah terjadi atau akan terjadi. Hipotesis merupakan pernyataan peneliti tentang hubungan antara variabel-variabel dalam penelitian, serta merupakan pernyataan paling spesifik.

Tingkat profitabilitas bertujuan untuk mengukur efesiensi aktivitas perusahaan dan kemampuan perusahaan untuk memperoleh keuntungan. Untuk mengukur profitabilitas perusahaan, peneliti saat ini menggunakan Return on Asset. Rasio ini menggambarkan bahwa laba bersih yang dapat dicapai setiap total asset perusahaan (Munawari : 2001). Semakin besar profitabilitas maka akan semakin luas dalam pengungkapan laporan keuangan. Sebaliknya, semakin kecil profitabilitas maka akan semakin sempit dalam pengungkapan laporan keuangan.

Hasil penelitian yang dilakukan Binsar H. Simanjuntak (2004) memperoleh bahwa profitabilitas berpengaruh signifikan terhadap pengungkapan laporan keuangan, namun penelitian yang dilakukan Dewi Agustina (2006) dan Kumala Dewi (2008) belum berhasil membuktikan adanya pengaruh signifikan antara profitabilitas terhadap pengungkapan laporan keuangan.

Leverage menunjukan sebagian besar ekuitas yang tersedia untuk memberikan jaminan terhadap hutang. Hutang disini meliputi hutang lancar dan hutang jangka panjang. Penggunaan hutang yang berhasil akan meningkatkan pendapatan perusahaan dan meningkatkan ekuitas perusahaan (Munawari : 2001). Semakin besar leverage menunjukan 
besarnya risiko dalam pembayaran hutang perusahaan, sehingga akan semakin sempit dalam pengungkapan laporan keuangan. Sebaliknya, semakin kecil leverage menunjukkan rendahnya risiko dalam pembayaran hutang perusahaan, maka akan semakin luas dalam pengungkapan laporan keuangan.

Kepemilikan Institusional adalah kepemilikan saham oleh badan institusional seperti institusi pemerintahan, institusi keuangan dan institusi yang berbadan hukum. Kepemilikan Institusional akan mencoba untuk mempengaruhi manajemen perusahaan dalam mengelola urusan internal perusahaan dikarenakan kepemilikan institusional mempunyai kepemilikan yang agak besar dalam perusahaan. Bila kepemilikan institusional meningkat menunjukkan semakin banyak pihak yang membutuhkan informasi tentang perusahaan, semakin banyak pula detail-detail butir pengungkapan laporan keuangan yang dituntut untuk dibuka dan dengan demikian pengungkapan laporan keuangan akan semakin luas.

Kumala Dewi (2008) menyatakan bahwa kepemilikan institusional memiliki hubungan positif yang signifikan terhadap pengungkapan laporan keuangan. Hasil ini mengindikasikan bahwa bila kepemilikan institusional meningkat menunjukkan bahwa pengungkapan laporan keuangan akan semakin lengkap.

Latar belakang masuknya variabel status perusahaan didorong oleh suatu alasan sederhana yaitu bahwa perusahaan dengan status yang berbeda akan memiliki stakeholder yang berbeda, sehingga tingkat kelengkapan pengungkapan yang harus dilakukan berbeda (Dewi Agustina, 2006). Perusahaan yang berbasis asing (PMA) mungkin melakukan pengungkapan laporan keuangan yang lebih luas dibanding perusahaan yang berbasis dalam negeri (PMDN).

Penelitian yang dilakukan oleh Dewi Agustina (2006) memperoleh hasil bahwa status perusahaan tidak berpengaruh terhadap pengungkapan laporan keuangan, namun secara teori dengan status perusahaan yang baik akan semakin luas pula pengungkapan laporan keuangan perusahaan.

Berdasarkan uraian diatas maka dapat dirumuskan hipotesis secara parsial dapat dirumuskan sebagai berikut :

H1 : Profitabilitas berpengaruh signifikan terhadap Pengungkapan Laporan Keuangan

H2 : Leverage berpengaruh signifikan terhadap Pengungkapan Laporan Keuangan

H3 : Struktur kepemiikan institusional berpengaruh signifikan terhadap Pengungkapan Laporan Keuangan 
H4 : Status Perusahaan berpengaruh signifikan terhadap Pengungkapan Laporan Keuangan

\section{METODE PENELITIAN}

\section{Populasi dan Sampel}

Populasi dalam penelitian ini adalah seluruh perusahaan manufaktur yang terdapat di Bursa Efek Indonesia (BEI). Sampel dalam penelitian ini adalah 58 perusahaan manufaktur terdapat di Bursa Efek Indonesia (BEI), dengan teknik pengambilan sampel random sampling.

\section{Operasionalisasi Variabel}

a. Pengungkapan laporan keuangan diukur menggunakan indeks Wallace untuk mengukur berapa banyak laporan keuangan yang diungkapkan oleh perusahaan. Kategori pengungkapan yang digunakan dalam penelitian ini adalah kategori pengungkapan wajib berisi 99 item pengungkapan laporan keuangan. Perhitungan untuk menentukan angka indeks dengan formula Wallace sebagai berikut :

$$
\text { Indeks Disclosure }=\frac{\mathbf{n}}{\mathbf{N}}
$$

$\mathrm{n}=$ jumlah butir pengungkapan yang terpenuhi

$\mathrm{N}=$ jumlah butir pengungkapan yang mungkin terpenuhi keseluruhan yang berjumlah 99 item

b. Profitabilitas bertujuan untuk mengukur efisiensi aktivitas perusahaan dan kemampuan perusahaan untuk memperoleh keuntungan. Untuk mengukur profitabilitas dapat digunakan rasio Return on Asset (Kasmir 2008:200) yang dirumuskan sebagai berikut :

$$
\text { ROA }=\frac{\text { EAT }}{\text { Total Aktiva }}
$$

c. Leverage menunjukkan seberapa besar ekuitas yang tersedia untuk memberikan jaminan terhadap hutang. Hutang disini meliputi hutang lancar dan hutang jangka panjang. Leverage sering juga disebut dengan solvabilitas. Untuk mengukur leverage dapat digunakan Debt to Equity Ratio (Kasmir 2008: 156) dan dapat dirumuskan sebagai berikut :

$$
\text { DER }=\frac{\text { Total Hutang }}{\text { Total Ekuitas }}
$$

d. Kepemilikan institusional adalah kepemilikan saham oleh badan institusi, seperti institusi keuangan, bank, dan perusahaan lain. Kepemilikan institusional dihitung dengan cara membandingkan antara jumlah saham yang dimiliki oleh institusional dengan total saham 
perusahaan yang beredar (Arumi Purwandari 2012) dan dapat dirumuskan sebagai berikut :

Kepemilikan institusional $=\frac{\text { Jumlah saham yang dimiliki Institusi }}{\text { Jumlah saham yang beredar }}$

e. Status perusahaan dihitung menggunakan kategorikal yaitu dengan pemberian skor. Skor 1 untuk penanaman modal dalam negeri dan skor 0 untuk penanaman modal asing. Kelompok yang dikategorikan 1 disebut included group dan kelompok yang dikategorikan 0 disebut excluded group (Ghozali:2005), sehingga dalam penelitian ini, peneliti mengkategorikan penanaman modal dalam negeri dengan skor 1 dan penanaman modal asing dengan skor 0 .

\section{Teknik Analisis Data}

\section{a. Uji Asumsi Klasik}

Sebelum model regresi digunakan untuk menguji hipotesis, tentunya model tersebut harus bebas dari gejala asumsi klasik karena model yang baik harus memenuhi kriteria BLUE (Best Linear Unbiased Estimator). Adapun uji asumsi klasik yang digunakan adalah, Uji Normalitas, normalitas diuji dengan melihat grafik histogram (Ghozali, 2013). Uji Multikolinieritas, pengujian multikolinearitas dilakukan dengan melihat VIF (Variance Inflation Factor) antar variabel independen, (Ghozali, 2013). Uji Autokorelasi, pengujian autokorelasi menggunakan uji Durbin Watson (DW test). Uji Heteroskedastisitas Uji heteroskedastisitas dilakukan dengan melihat grafik plot antara nilai prediksi variabel terikat(dependen) yaitu ZPRED dengan residualnya SRESID (Ghozali, 2013:139).

\section{b. Pengujian hipotesis penelitian}

Pengujian hipotesis dalam penelitian ini digunakan untuk menguji pengaruh variabel independen yaitu profitabilitas, leverage, struktur kepemilikan institusional, dan status perusahaan terhadap variabel dependen yaitu pengungkapan laporan keuangan. Model regresi yang dikembangkan untuk menguji hipotesis-hipotesis yang telah dirumuskan dalam penelitian ini adalah:

$$
\mathbf{Y}=\mathbf{a}+\mathbf{b}_{1} \mathbf{X}_{1}+\mathbf{b}_{2} \mathbf{X}_{2}+\mathbf{b}_{3} \mathbf{X}_{3}+\mathbf{b}_{4} \mathbf{X}_{4}+\grave{e}
$$

Keterangan :

$\mathrm{Y}=$ indeks pengungkapan laporan keungan

$\mathrm{a}=$ Konstanta 
$b_{1}, b_{2}, b_{3}, b_{4}=$ Koefisien regresi

$\mathrm{X}_{1}=$ Profitabilitas

$\mathrm{X}_{2}=$ Leverage

$\mathrm{X}_{3}=$ Kepemilikan Institusional

$\mathrm{X}_{4}=$ Status Perusahaan

è $=$ error term

\section{HASIL DAN PEMBAHASAN}

\section{Hasil Uji Asumsi Klasik}

\section{a. Uji Normalitas}

Berdasarkan grafik histogram, dapat dilihat bahwa gambar histogram telah berbentuk lonceng dan tidak menceng kekanan atau ke kiri yang menunjukkan bahwa data telah terdistribusi secara normal, hal ini menunjukkan bahwa model regresi tidak menyalahi asumsi normalitas.

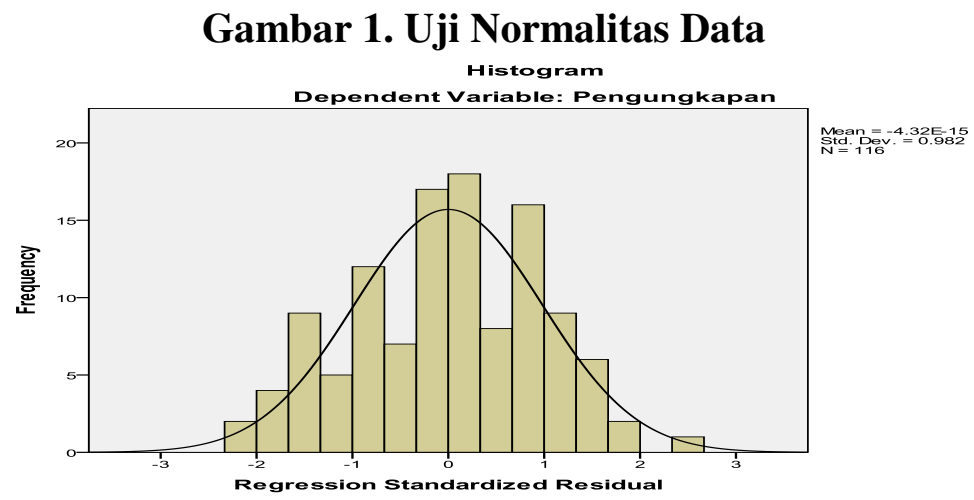

\section{b. Uji Multikolinearitas}

Uji multikolinearitas dapat dilihat dengan memperhatikan Variance Inflation Factors (VIF). Semua variabel independen memiliki nilai tolerance lebih dari 0,10 dan variance inflation factor (VIF) kurang dari 10, artinya bahwa tidak ada korelasi antara variabel independen.

Tabel 2. Hasil Uji Multikolinearitas

\begin{tabular}{|c|c|c|c|c|c|}
\hline \multirow[b]{2}{*}{ Model } & \multicolumn{2}{|c|}{ Unstandardized Coefficients } & \multirow{2}{*}{$\begin{array}{c}\begin{array}{c}\text { Standardized } \\
\text { Coefficients }\end{array} \\
\text { Beta }\end{array}$} & \multicolumn{2}{|c|}{ Collinearity Statistics } \\
\hline & $B$ & Std. Error & & Tolerance & VIF \\
\hline $\begin{array}{ll}1 & \text { (Constant) }\end{array}$ & .658 & .027 & & & \\
\hline ROA & -.002 & .001 & -.262 & .936 & 1.068 \\
\hline DER & .013 & .008 & .153 & .923 & 1.084 \\
\hline $\mathrm{KI}$ & -.001 & .000 & -.177 & .988 & 1.012 \\
\hline $\mathrm{SP}$ & .002 & 013 & .011 & .996 & 1.004 \\
\hline
\end{tabular}




\section{c. Uji Autokorelasi}

Pada data penelitian ini, didapatkan nilai Durbin-Watson $(\mathrm{DW})=$ 2,143 seperti terlihat pada tabel 3. Dengan jumlah sampel penelitian $(\mathrm{n})=$ 116 dan jumlah variabel independen $=4(\mathrm{~K}=4)$, maka diperoleh nilai du $=$ 1,7690 dan $\mathrm{dl}=1,6265$. Dengan demikian nilai $\mathrm{du}<\mathrm{d}<4$-du $(1,7690<$ $2,143<2,3735)$, sehingga dapat disimpulkan bahwa tidak terdapat autokorelasi positif atau negatif (bebas uji autokorelasi) pada persamaan regresi penelitian ini.

Tabel 3. Uji Autokorelasi

Model Summary

\begin{tabular}{|l|r|r|r|r|r|}
\hline Model & $\mathrm{R}$ & $\mathrm{R}$ Square & $\begin{array}{c}\text { Adjusted R } \\
\text { Square }\end{array}$ & $\begin{array}{c}\text { Std. Error of the } \\
\text { Estimate }\end{array}$ & Durbin-Watson \\
\hline 1 & $.385^{\mathrm{a}}$ & .148 & .117 & .06847 & 2.143 \\
\hline
\end{tabular}

a. Predictors: (Constant), SP, ROA, KI, DER

b. Dependent Variable: Pengungkapan

\section{d. Uji Heterokedastisitas}

Uji heterokedastisitas dapat dilihat dari grafik scatterplot. Grafik scatterplot menunjukkan bahwa pola yang dibentuk menyebar baik di atas maupun di bawah angka nol pada sumbu Y. Maka dapat disimpulkan model regresi bebas dari heterokedastisitas atau terjadi homokedastisitas.

\section{Gambar 2. Uji Heteroskedastisita}

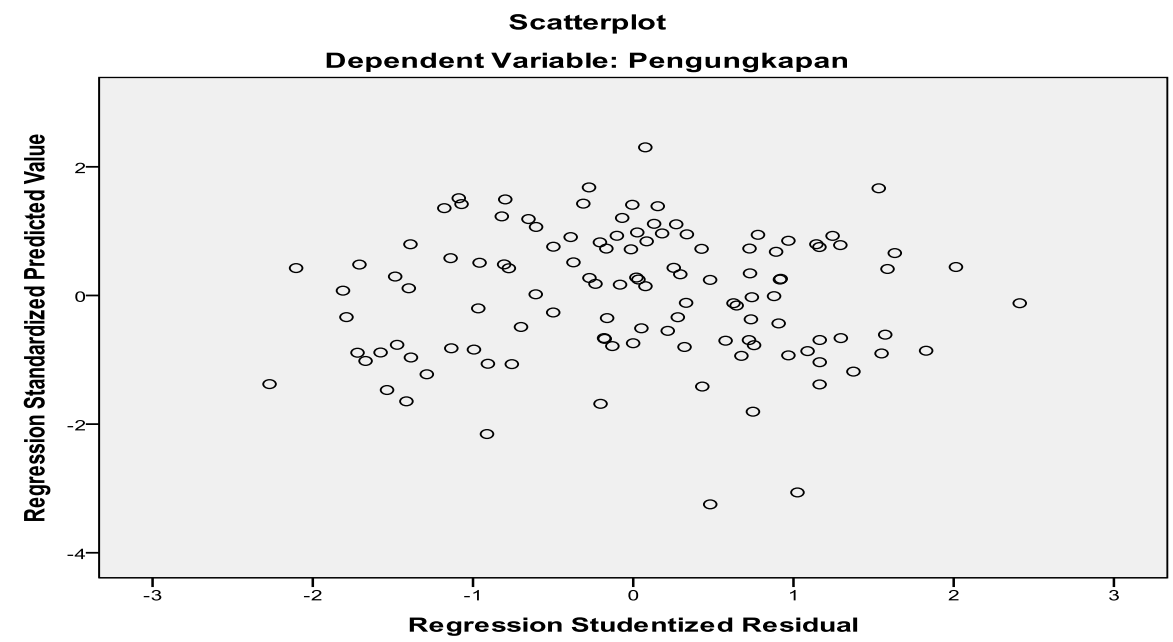




\section{Pengujian Hipotesis}

\section{a. Uji Statistik $\mathbf{t}$}

Uji t dilakukan untuk mengetahui hubungan antara variabel-variabel independen terhadap variabel dependen secara parsial (individu). Dengan menggunakan tingkat signifikan $(\alpha=5 \%)$, jika nilai signifikan $\mathrm{t}>0,05$ maka H0 diterima, artinya tidak terdapat pengaruh yang signifikan secara parsial dari variabel independen terhadap variabel dependen. Sebaliknya, jika nilai signifikan $\mathrm{t}<0,05$ maka $\mathrm{H} 2, \mathrm{H} 3$, dan $\mathrm{H} 4, \mathrm{H} 5$ diterima, artinya terdapat pengaruh yang signifikan secara parsial dari variabel independen dan variabel dependen.

Tabel 4. Hasil Uji Statistik t Coefficients $^{\mathrm{a}}$

\begin{tabular}{|c|c|c|c|c|c|c|}
\hline \multirow[b]{2}{*}{ Mode } & & \multicolumn{2}{|c|}{ Unstandardized Coefficients } & \multirow{2}{*}{$\begin{array}{c}\text { Standardized } \\
\text { Coefficients } \\
\text { Beta }\end{array}$} & \multirow[b]{2}{*}{$t$} & \multirow[b]{2}{*}{ Sig. } \\
\hline & & $\mathrm{B}$ & Std. Error & & & \\
\hline \multirow[t]{5}{*}{1} & (Constant) & 658 & .027 & & 24.372 & .000 \\
\hline & ROA & -.002 & .001 & -.262 & -2.893 & .005 \\
\hline & DER & 013 & .008 & 153 & 1.677 & .096 \\
\hline & $\mathrm{KI}$ & -.001 & .000 & -177 & -2.005 & .047 \\
\hline & SP & .002 & 013 & 011 & .120 & .905 \\
\hline
\end{tabular}

Dari tabel 4 di atas, dapat rumuskan persamaan regresi linier berganda sebagai berikut :

\section{Indeks Pengungkapan $=0.658-0.002$ ROA+ 0,013 DER- 0,001 KI $+0.002 \mathrm{SP}+\mathrm{e}$}

Berdasarkan hasil perhitungan menggunakan SPSS 19, dapat dilihat bahwa terdapat variabel independen, yaitu variabel profitabilitas (ROA) yang berpengaruh signifikan terhadap variabel dependen yaitu pengungkapan laporan keuangan, dengan tingkat signifikansi t sebesar 0,005 yang berarti lebih kecil dari tingkat signifikansi sebesar 0,05. Variabel leverage (DER) tidak signifikan terhadap pengungkapan laporan keuangan, dengan tingkat signifikansi t 0,096 yang berarti lebih besar dari tingkat signifikansi sebesar 0,05. Variabel kepemilikan institusional berpengaruh signifikan terhadap pengungkapan laporan keuangan, dengan tingkat signifikansi t sebesar 0,047 yang berarti lebih kecil dari tingkat signifikansi sebesar 0,05. Sedangkan status perusahaan tidak memiliki pengaruh yang signifikan terhadap pengungkapan laporan keuangan dengan tingkat signifikansi t sebesar 0,905 yang berarti lebih besar dari tingkat signifikansi sebesar 0,05 . 


\section{b. Uji Statistik F}

Pengujian ini dimaksudkan untuk mengetahui pengaruh antara variabel indipenden dan variabel dependen secara bersama-sama (simultan). Signifikansi model regresi secara simultan diuji dengan melihat perbandingan antara F-tabel dan F-hitung. Selain itu akan diihat nilai signifikansi, dimana jika nilai signifikan dibawah 0,05 maka variabel independen dinyatakan berpengaruh terhadap variabel dependen. Uji $F$ digunakan untuk menguji hubungan regresi antar variabel independen dengan seperangkat terhadap variabel dependen.

Tabel 5. Hasil Regresi Uji F

\begin{tabular}{|ll|r|r|r|r|r|}
\hline Model & & Sum of Squares & Df & Mean Square & F & Sig. \\
\hline 1 & Regression & .090 & 4 & .023 & 4.821 & $.001^{\mathrm{a}}$ \\
& Residual & .520 & 111 & .005 & & \\
& Total & .611 & 115 & & & \\
\hline
\end{tabular}

a. Predictors: (Constant), SP, ROA, KI, DER

b. Dependent Variable: Pengungkapan

Berdasarkan hasil analisis regresi dapat diketahui bahwa keempat variabel independen secara bersama-sama berpengaruh signifikan terhadap pengungkapan laporan keuangan. Hal ini dapat dibuktikan dari nilai signifikan uji $\mathrm{F}$ sebesar 0,001 yang berarti lebih kecil dari tingkat signifikasinya yakni sebesar 0,05. Berdasarkan hasil tersebut maka dapat disimpulkan profitabilitas, leverage, struktur kepemilikan dan status perusahaan secara simultan berpengaruh signifikan terhadap pengungkapan laporan keuangan.

\section{c. Pengaruh Profitabilitas terhadap Pengungkapan Laporan Keuangan}

Berdasarkan hasil analisis uji t untuk variabel profitabilitas (ROA) menunjukkan nilai t-hitung sebesar -2,893 (karena daerah kritis tidak terpengaruhi oleh adanya nilai negatif) lebih besar dari t-tabel yaitu 1,981 $(2,893>1,981)$ dengan tingkat signifikan 0,005 lebih kecil dari tingkat keyakinan $0,05(0,005<0,05)$ maka hipotesis profitabilitas berpengaruh signifikan terhadap pengungkapan laporan keuangan diterima dan hipotesis yang menyatakan profitabilitas tidak berpengaruh signifikan terhadap pengungkapan laporan keuangan ditolak, yang berarti bahwa variabel profitabilitas (return on asset) secara parsial berpengaruh negatif dan signifikan terhadap pengungkapan laporan keuangan pada perusahaan manufaktur yang terdaftar di Bursa Efek Indonesia. Hal ini terjadi karena para pengguna laporan keuangan hanya memperhatikan laba perusahaan 
sehingga perusahaan tidak melakukan pengungkapan laporan keuangan yang lebih tentang profitabilitas perusahaan.

Hasil penelitian ini sesuai dengan penelitian yang dilakukan oleh Arumi Purwandari (2012) dan B Simanjuntak (2004) dan tidak sesuia dengan hasil penelitian yang dilakukan oleh Dewi Agustin (2006) dan Kumala Dewi (2008).

\section{d. Pengaruh Leverage terhadap Pengungkapan Laporan Keuangan}

Berdasarkan hasil analisis uji t untuk variabel leverage (debt to equity ratio) menunjukkan nilai t-hitung sebesar 1,677 dengan signifikan 0,096. Nilai t-hitung 1,677 < t-tabel 1,981, sedangkan tingkat signifikansi 0,096 lebih besar dari tingkat keyakinan 5\% $(0,096>0,05)$ sehingga hipotesis yang menyatakan leverage berpengaruh signifikan terhadap pengungkapan laporan keuangan ditolak dan hipotesis yang menyatakan leverage tidak signifikan terhadap pengungkapan laporan keuangan diterima. Hal ini berarti bahwa variabel leverage (debt to equity ratio) secara parsial berpengaruh positif dan tidak signifikan terhadap pengungkapan laporan keuangan yang terdaftar di Bursa Efek Indonesia.

Hal ini terjadi karena penggunaan pinjaman tentunya menuntut adanya pertanggungjawaban perusahaan dalam pengembalian pinjaman. Pihak kreditor akan selalu memantau dan memerlukan informasi mengenai keadaan finansial debitor untuk meyakinkan bahwa debitor akan dapat memenuhi kewajibannya pada saat jatuh tempo. Seiring dengan tuntutan kreditor akan informasi tersebut, maka perusahaan dengan rasio hutang (leverage) yang tinggi akan melakukan pengungkapan laporan keuangan yang lebih luas. Tambahan informasi diperlukan untuk menghilangkan keraguan pemegang obligasi terhadap dipenuhinya hak-hak mereka sebagai kreditur. Oleh karena itu perusahaan dengan rasio leverage yang tinggi memiliki kewajiban untuk memenuhi kebutuhan informasi kreditur jangka panjang, Sehingga perusahaan akan menyediakan informasi secara lebih komprehensif. Hasil penelitian ini sesuai dengan penelitian yang dilakukan oleh Dewi Agustin (2006) dan tidak sesuai dengan hasil penelitian yang dilakukan oleh B.Simanjuntak (2004).

\section{e. Pengaruh Struktur Kepemilikan terhadap Pengungkapan Laporan Keuangan}

Hasil analisis uji $\mathrm{t}$ untuk variabel kepemilikan institusional menunjukkan nilai t-hitung sebesar -2,005 dengan signifikan 0,047. Nilai thitung -2,005>t-tabel 1,981, sedangkan tingkat signifikansi 0,047 lebih kecil dari tingkat keyakinan $5 \%(0,047<0,05)$ sehingga hipotesis yang 
menyatakan struktur kepemilikan tidak signifikan terhadap pengungkapan laporan keuangan ditolak dan hipotesis yang menyatakan struktur kepemilikan berpengaruh signifikan terhadap pengungkapan laporan keuangan diterima. Hal ini berarti bahwa variabel struktur kepemilikan secara parsial berpengaruh negatif dan signifikan terhadap pengungkapan laporan keuangan yang terdaftar di Bursa Efek Indonesia. Hal ini terjadi karena besar atau kecilnya struktur kepemilikan institusional tidak menjamin luasnya pengungkapan laporan keuangan. Perusahaan dengan struktur kepemilikan institusional yang besar lebih menggunakan analisis rasio keuangan dibandingkan memperhatikan pengungkapan laporan keuangan, karena hal itu perusahaan beranggapan tidak perlu melakukan pengungkapan laporan keuangan yang lebih luas kepada masyarakat sehingga struktur kepemilikan institusional berpengaruh negatif terhadap pengungkapan laporan keuangan.

Hasil penelitian ini sesuai dengan penelitian yang dilakukan oleh Wiwik Pujiati (2011) dan tidak sesuia dengan hasil penelitian yang dilakukan oleh Arumi Purwandari (2012) dan Kumala Dewi (2008).

\section{f. Pengaruh Status Perusahaan terhadap Pengungkapan Laporan Keuangan}

Hasil analisis uji t untuk variabel status perusahaan menunjukkan nilai t-hitung sebesar 0,120 dengan signifikan 0,905. Nilai t-hitung 0,120 < ttabel 1,981, sedangkan tingkat signifikansi 0,905 lebih besar dari tingkat keyakinan $5 \%(0,905>0,05)$ sehingga hipotesis yang menyatakan status perusahaan tidak signifikan terhadap pengungkapan laporan keuangan diterima dan hipotesis yang menyatakan status perusahaan berpengaruh signifikan terhadap pengungkapan laporan keuangan ditolak. Hal ini berarti bahwa variabel status perusahaan secara parsial berpengaruh positif dan tidak signifikan terhadap pengungkapan laporan keuangan yang terdaftar di Bursa Efek Indonesia. Dengan demikian pengungkapan laporan keuangan yang dilakukan oleh perusahaan tidak berkaitan dengan meningkat atau menurunnya status perusahaan.

Hasil penelitian ini sesuai dengan penelitian yang dilakukan oleh Arumi Purwandari (2012) dan tidak sesuia dengan hasil penelitian yang dilakukan oleh Kumala Dewi (2008). 


\section{KESIMPULAN DAN SARAN}

\section{Kesimpulan}

a. Variabel independen profitabilitas dan struktur kepemilikan secara parsial berpengaruh negatif dan signifikan terhadap pengungkapan laporan keuangan pada perusahaan manufaktur yang terdaftar di Bursa Efek Indonesia.

b. Variabel independen leverage dan status perusahaan secara parsial berpengaruh positif dan tidak signifikan terhadap pengungkapan laporan keuangan pada perusahaan manufaktur yang terdaftar di Bursa Efek Indonesia

c. Persamaan regresi linear berganda yang diperoleh dari hasil penelitian adalah $\mathrm{Y}=0.658-0.002 \mathrm{ROA}+0,013 \mathrm{DER}-0,001 \mathrm{KI}+$ $0.002 \mathrm{SP}+\mathrm{e}$.

d. Nilai koefisien regresi korelasi sebesar 0,385, artinya profitabilitas, leverage, struktur kepemilikan dan status perusahaan memiliki hubungan positif terhadap pengungkapan laporan keuangan di masa mendatang pada perusahaan manufaktur di Bursa Efek Indonesia.

e. Nilai koefisien determinasi (adjusted $R$ Square) sebesar 0.117, artinya pengungkapan laporan keuangan dapat dijelaskan oleh profitabilitas, leverage, struktur kepemilikan dan status perusahaan sebesar $11,7 \%$ sedangkan sisanya 88,3\% dijelaskan oleh faktor lain.

\section{Saran.}

a. Peneliti selanjutnya perlu menambahkan variabel independen seperti ukuran perusahaan, umur perusahaan, rasio keuangan lainya dan kepemilikan publik, kepemilikan manajerial, peraturan bapepam dan variabel lainnya yang berpotensi berpengaruh terhadap indeks pengungkapan laporan keuangan.

b. Bagi kreditor, sebelum kreditor mengambil keputusan agar mengetahui bahwa perusahaan dalam menyajikan pengungkapan laporan keuangan tidak dipengaruhi oleh kemampuan perusahaan dalam membayar hutang jangka panjang dan jangka pendek.

c. Bagi investor dan calaon investor, sebaiknya tidak hanya memperhatikan analisis rasio keuangan tetapi perlu memperhatikan pengungkapan laporan keuangan sebelum mengambil keputusan menginvestasikan dananya atau tidak ke perusahaan. 


\section{DAFTAR PUSTAKA}

Agustina, Dewi, 2006. Pengaruh Profitabilitas, Leverage, Kepemilikan Publik dan Status Terhadap Pengungkapan Laporan Keuangan. Jurnal Bisnis dan Akuntansi Vol. 8 No. 3 Desember 2008, hal. 219246.

Dewi, Kumala, 2008. Pengaruh Luas Pengungkapan Laporan Keuangan Tahunan Pada Perusahaan Manufaktur di Bursa Efek Indonesia terhadap Keputusan Oleh Investor. Jurnal Penelitian.

Eugene F. Brighand, Joel F Houston. 2001. Manajemen Keuangan. Edisi Kedelapan. Jakarta : Erlanggga.

Fitriany, 2001.Pengungkapan Pada Laporan Keuangan Perusahaan Publik, Simposium Nasional Akuntansi IV, Bandung.

Ghozali, Imam, 2006, Aplikasi Analisis Multivariate, Badan Penerbitan Universitas Diponegoro, Semarang.

Hery, 2009. Teori Akuntansi. Jakarta : Kencana Prenada Media Group.

http//www.bapepam.co.id

Ikatan Akuntansi Indonesia, 2009.Standar Akuntansi Keuangan. Salemba empat, Jakarta. Indonesia Capital Market Directory 2011.

Kieso, Donald E, dkk.2002. Akuntansi Intermediate, Edisi Kesepuluh, Jakarta : Erlangga.

Kasmir, 2008.Analisis Laporan Keuangan, Jakarta : PT. Raya Grafindo Persada.

Kuncoro, Mudrajat, 2009. Metode Riset untuk Bisnis dan Ekonomi, Edisi Ketiga, Jakarta : Erlangga.

Munawir, 2000, Analisa Laporan Keuangan, Edisi Keempat, Penerbit Liberty, Yogyakarta.

Purwandari, Arumi, 2012. Pengaruh Profitabilitas, Leverage, Struktur Kepemilikan dan Status Perusahaan Terhadap Pengungkapan Laporan Keuangan Pada Perusahaan Manufaktur Yang Terdaftar Di Bursa Efek Indonesia. Jurnal Portal Garuda.

Santoso, Singgih, 2006. Menggunakan SPSS Untuk Statistik Parametrik. Penerbit PT.Elex Media Kamputindo Gramedia, Jakarta.

Simanjuntak, Binsar H, 2004. Fakto-faktor yang mempengaruhi Kelengkapan Pengungkapan Laporan Keuangan pada Perusahaan 
Manufaktur yang Terdaftar di Bursa Efek Jakarta. Jurnal Riset Akuntansi Indonesia Vol. 7 No. 3 September 2004.

Sugiyono, Wibowo, Eri, 1999. Statistik untuk Penelitian dan Aplikasinya dengan SPSS 10,0 for Windows, Alfabeta, Bandung.

Supranto, 2008. Statistik Teori Dan Aplikasi, Edisi Ketujuh, Penerbit Erlangga Jakarta. 